\title{
The Online Arbitration in E-Commerce Dispute Resolution During Covid- 19 Pandemic
}

\author{
Mohammad Ghozali $^{*}$ and Budi Ispriyarso ${ }^{* *}$ \\ *) Master of Law, Universitas Diponegoro, Email: \\ mohammadghozali67@gmail.com \\ ${ }^{* *}$ Faculty of Law, Universitas Diponegoro, Email: budiispriyarso@gmail.com
}

\begin{abstract}
The Covid-19 pandemic has made online buying and selling activities increasing. E-commerce is full of risks, especially because the consumers have the obligation to make any advance payment while they cannot see the condition or quality of the goods they ordered. With the emergence of business disputes that occur both online and offline, and with the development of increasingly sophisticated technology, it is expected that the settlement of business disputes can be resolved online. The purpose of this study was to analyze the settlement of legal disputes against online buying and selling transactions during the Covid-19 pandemic which was carried out through online arbitration. The research method used was the normative juridical method, which was a method that seeks to analyze dispute resolution carried out through online arbitration which was then linked to the provisions of laws and regulations. The process of conducting online arbitration is by using the internet as media. The room for communication is more like a chat room based on real-time audio-visual streaming. With the application to communicate, the parties can convey their data, facts, information, or responses through this platform. Legal sanctions against online buying and selling transactions that do not match the order are regulated in two general rules (Lex Generalis) and special rules (Lex Specialist).

Keywords: E-Commerce; Covid-19, Online Arbitration; Legal Sanctions.
\end{abstract}

\section{Introduction}

Indonesian people, especially those in urban areas, are very dependent on the internet because almost all activities always involve the internet and information technology. So, do not be surprised if the internet has now become a basic need for some people, especially for those who use the internet for business purposes (ecommerce). ${ }^{1}$ The use of the internet for business transaction activities is known as Electronic Commerce (E-Commerce). E-Commerce can occur between business organizations and consumers, including the use of the Internet and the World Wide Web for selling products and services to consumers. ${ }^{2}$

Pandemic Covid-19 makes the activity of buying and selling online is increasing. Almost everyone switches to shopping for all their needs through electronic media. Apart from being practical, this is also done to prevent physical contact and reduce the risk of

\footnotetext{
${ }^{1}$ Mahir Pradana, 'Klasifikasi Jenis-Jenis Bisnis E-Commerce Di Indonesia', Neo-Bis, 9.2 (2015), 32-40. p. 33.

2 Shabur Mirftah Maulana, 'Implementasi E-Commerce Sebagai Media Penjualan Online', Jurnal Administrasi Bisnis, 29.1 (2020), 1-9. p. 2.
} 
transmitting the virus. In early 2020, the world was shocked by an outbreak of new pneumonia that started in Wuhan, Hubei Province, which then spread rapidly to more than 190 countries and territories. This outbreak was named Corona Virus Disease 2019 (Covid-19) which was caused by Severe Acute Respiratory Syndrome Coronavirus-2 (SARS-CoV-2). The spread of this disease has had a wide social and economic impact. ${ }^{3}$ All sectors are affected by Covid-19, especially the health sector and the economic sector.

Covid-19 is a disease caused by infection with the SARS-CoV-2 virus, first identified in the city of Wuhan, in the Hubei province of China in December 2019. Covid-19 has spread to various countries in the world, including Indonesia. ${ }^{4}$ Since Covid-19 spread, large companies have not been spared the impact which resulted in a reduction in the number of employees. ${ }^{5}$ The spread of the coronavirus plague makes the transaction which initially conducts conventionally switch to online media or e-commerce. The use of electronic media, namely E-commerce, is indeed very practical but does not always guarantee the safety of the goods purchased by consumers. There are many cases where the item that has been purchased does not match the one in the photo. This is certainly not a bit detrimental to consumers as buyers as well as users of e-commerce services. So even though buying and selling activities have begun to shift to online media due to the spread of the coronavirus.

According to Rahmati, E-Commerce stands for Electronic Commerce, which means a marketing system using electronic media. E-Commerce includes the distribution, sale, purchase, marketing, and service of a product that is carried out in an electronic system such as the Internet or other forms of computer network. ${ }^{6} \mathrm{E}$ Commerce allows easy transactions between businesses or between businesses and consumers either in and also outside Indonesia. E-commerce allows businesses actors in Indonesia to establish business relationships with partners abroad. Vice versa, consumers in Indonesia easily get the goods or services they want from abroad. Most transactions in e-commerce are done online, both between business people and between business people and consumers. ${ }^{7}$

The impact of the internet as a result of advances in the development of information technology for consumers on the one hand has changed consumer behaviour to become increasingly critical and selective in determining the product they will choose. Likewise, for manufacturers, this progress has a positive impact in facilitating product marketing to save costs and time. On the other hand, because the two parties

\footnotetext{
3 J Adityo Susilo, 'Coronavirus Disease 2019: Tinjauan Literatur Terkini', Jurnal Penyakit Dalam Indonesia, 7.1 (2019), 45-67. p. 45.

4 Rizal Fadli, 'Coronavirus', Halodoc, 2021 <https://www.halodoc.com/kesehatan/coronavirus> [accessed 29 June 2021].

${ }^{5}$ Christopher Stanton Alexander W. Bartik, Marianne Betrand, Zoe Cullen, Edward L. Glaeser, Michael Luca, 'The Impact of Covid-19 on Small Business Outcomes and Expectations', Proceedings of the National Academy of Sciences, 117.30 (2020), 17656-17666. p. 17657.

${ }^{6}$ Yulistia, 'Analisis Pengaruh Efektivitas Dan Manfaat E-Commerce Terhadap Sikap Dan Perilaku Pengguna Dengan Menggunakan Metode TAM (Studi Kasus: UKM Kota Palembang)', JATISI (Jurnal Teknik Informatika Dan Sistem Informasi), 4.1 (2017), 93-100. p. 95.

${ }^{7}$ Paustinus Siburian, Arbitrase Online (Alternatif Penyelesaian Sengketa Perdagangan Secara Elektronik) (Jakarta: Djambata, 2004). p. 2.
} 
do not physically meet, the possibility of fraud or error is a major concern that requires greater handling. The negative impact of e-commerce itself tends to harm consumers. Among them are matters relating to the products ordered that are not following the products offered, and other matters that are not in accordance with the previous agreement.

E-commerce is very risky, full of risks, especially because the consumers have the obligation to make any advance payment while they cannot see the condition or quality of the goods they ordered. Furthermore, payments made electronically, either by bank transfer or, moreover, by filling in a credit number on the internet, are very open to the possibility of civil and criminal fraud, while there is no exact guarantee that the ordered goods have been delivered according to order. So with the presence of e-commerce, it is expected that there will be an informal settlement of procedures that are fast and low-cost dispute resolution through conventional methods will waste time and cost a lot of money.

The litigation process for disputes arising from e-commerce is not easy, timeconsuming, and expensive due to the low transaction value and physical distance between the parties. Furthermore, courts may lack the resources and expertise to keep up with the ever-emerging growth of cross-border disputes arising from ecommerce. ${ }^{8}$ With the emergence of business disputes that occur both online and offline, and with the development of increasingly sophisticated technology, it is expected that the settlement of business disputes can be resolved online. In the midst of the confusion over the legal system is not easy to follow the developing and rapid advance, plus an outbreak of coronavirus which is forcing people to do a variety of activities through online media, technology has given rise to the notion of online dispute resolution, in this case, will talk about online arbitration. ${ }^{9}$

Dispute resolution through conventional methods will waste time and cost a lot of money. When alternative dispute resolution efforts cannot be achieved, the parties can submit a settlement effort through an arbitration institution. So it can be said that arbitration is an alternative intermediary for dispute resolution and is final for the parties. ${ }^{10}$ Arbitration is a way of settling a civil dispute outside the general court based on an arbitration agreement made in writing by the disputing parties.

Arbitration is often chosen because it has various advantages which are considered better than other settlements. Technological developments have led to the development of arbitration that can be carried out online via the internet to assist the disputing parties. ${ }^{11} \mathrm{It}$ is because if the online arbitration implementation arrangements are delivered to the parties to organize themselves, it is feared there are no basic standards concerning the implementation of the arbitration online effectively and

\footnotetext{
${ }^{8}$ Cortes, Pablo Online Dispute Resolution for Consumer in the European Union (New York: Routledge, 2011). p. 28.

${ }^{9}$ Susanti Adi Nugroho, Mediasi Sebagai Alternatif Penyelesaian Sengketa (Jakarta: Telaga Ilmu Indonesia, 2009). p. 40.

${ }^{10}$ Purwanto, Efektivitas Penerapan Alternative Dispute Resolution (Adr) Pada Penyelesaian Sengketa Bisnis Asuransi Di Indonesia (Samarinda: Risalah Hukum, 2015). p. 14.

${ }^{11}$ Rahadi Wasi Bintoro Rochani Urip, 'Alternatif Penyelesaian Sengketa Dalam Transaksi Elektronik (ECommerce)', Jurnal Dinamika Hukum, 13.1 (2013), 123-138. p. 126.
} 
efficiently. ${ }^{12}$ Online arbitration in the foreign discussion is also called Online Dispute Resolution (ODR). ODR was originally known as online ADR and was intended to be the network-based (online) equivalent of face-to-face offline dispute resolution processes, such as negotiation, mediation, and arbitration. ODR seeks to emulate traditional processes but remotely. ${ }^{13}$

Online arbitration is defined as a method of dispute resolution that includes all arbitration activities, including submissions to the arbitral tribunal and all proceedings taking place on the Internet via networks, e-mail, group chats, or online conferences. ${ }^{14}$ If the parties designate dispute resolution through a certain arbitration institution, the parties automatically also agree to apply the online procedure provided by the service provider concerned. ${ }^{15}$ Based on this description, this study specifically aims, firstly, to find out and analyze the process of resolving legal disputes through online arbitration in terms of online buying and selling transactions during the Covid-19 pandemic, secondly, knowing and analyzing legal sanctions against online buying and selling transactions that are not in accordance with by order.

\section{Research Methods}

The research method used was the normative juridical method. This method was used because this study outlines the problems that happen to be studied further using legal theories which were then associated with the legislation in force. ${ }^{16}$ The data used in this study was secondary data consisting of primary legal materials, secondary legal materials, and tertiary legal materials obtained through literature study. ${ }^{17}$ In this study, the writers tried to analyze dispute resolution law against online transactions during the pandemic Covid-19 conducted through online arbitration. The analytical approach used was descriptive-analytical, ${ }^{18}$ which is a method of analysis by describing the object of research.

\section{Results and Discussion}

\subsection{Legal Dispute Resolution Process through Online Arbitration in the Case of Online Buying and Selling Transactions during the Covid-19 Pandemic}

\footnotetext{
12 Moch Basarah, Prosedur Alternatif Penyelesaian Sengketa Arbitrase Internasional (Bandung: Genta Publishing, 2011).p.73.

${ }^{13}$ Ethan Katsh Orna Rabinovich-Einy, 'Digital Justice: Reshaping Boundaries in an Online Dispute Resolution Environment', International Journal of Online Dispute Resolution, 1.1 (2014), 1-10. p. 4.

${ }^{14}$ Armagan Ebru Bozkurt Yuksel, 'Online International Arbitration', Ankara Law Review, 4.1 (2007), 1-12. p. 7.

15 Priyatna Abdurrasyid, Arbitrase \& Alternatif Penyelesaian Sengketa (Jakarta: Fikahati Aneska, 2002). p. 118.

${ }^{16}$ Sri Mamudji Soerjono Soekanto, Penelitian Hukum Normatif; Suatu Tinjauan Singkat (Jakarta: Raja Grafindo Persada, 2001).p.13.

${ }^{17}$ Depri Liber Sonata, 'Metode Penelitian Hukum Normatif Dan Empiris Karakteristik Khas Dari Metode Meneliti Hukum', Fiat Justisia Jurnal IImu Hukum, 8.1 (2014), 15-35.p.21.

${ }^{18}$ Kornelius Benuf and Muhamad Azhar, 'Metodologi Penelitian Hukum Sebagai Instrumen Mengurai Permasalahan Hukum Kontemporer', Gema Keadilan, 7.1 (2020), 20-33.p. 26.
} 
Before discussing the process of resolving legal disputes through online arbitration in terms of online buying and selling transactions during the Covid-19 pandemic, it is necessary to first know about E-Commerce and Online Arbitration. Instant information processing from various parts of the world has proven to be a reliable source of knowledge and can be used for the development of modern science, business, and technology in communities elsewhere. Thanks to the convenience of this information technology, the internet is not only used as a mere means of correspondence but also for trade (business) relations. The use of internet media for trade, marketing, and business purposes is then popularly known as e-commerce.

Electronic Commerce or abbreviated as e-commerce, are business activities involving consumers, manufacturers, service providers, and intermediaries using computer networks, namely the Internet. E-commerce has covered the entire spectrum of commercial activity. ${ }^{19}$

Act No. 19 of 2016 concerning Information and Electronic Transactions states that: Electronic Transactions are legal acts carried out using computers, computer networks, and/or other electronic media (Article 1 number (2) of Act No.19 of 2016). Meanwhile, in a study conducted by the WTO, it is stated that Electronic Commerce may be simply defined as the production, advertising, sale, and distribution of products via telecommunication networks. ${ }^{20}$

The implementation of E-commerce in Indonesia is regulated by several ministries, namely: the Ministry of Communication and Information (Kominfo), the Ministry of Trade (Kemendag), and the Ministry of Finance (Kemenkeu) under the coordination of the Coordinating Minister for the Economy (Menko Perekonomian). ${ }^{21}$

Several international efforts in formulating rules relating to e-commerce have been initiated by several international organizations such as UNCTAD (United Nations Conference on Trade and Development), UNCITRAL (United Nations Commission on International Trade Law), OECD (Organization for Economic Cooperation and Development), and WTO (World Trade Organization). ${ }^{22} \mathrm{E}$-Commerce has several advantages including ${ }^{23}$ faster/convenient in purchasing, choice of products/services that continue to be improved, have more access to information, can improve prices (more competitive market), easier/faster-purchasing methods, increase the level of availability of customer service and Improve trust. Buying and selling transactions through E-Commerce media are very important in influencing competitive advantage in the world of trading business. Competitive advantage over competitors is obtained

\footnotetext{
${ }^{19}$ Sutan Remy Sjahdeini, 'E-Commerce (Tinjauan Dari Perspektif Hukum)', Jurnal Hukum Bisnis, 6.6 (2018), 23-43. p. 27.

${ }^{20}$ Ade Maman Suherman, Aspek Hukum Dalam Ekonomi Global (Bogor: Ghalia Indonesia, 2005). p. 71.

${ }^{21}$ Wicaksono Febriantoro, 'Kajian Dan Strategi Pendukung Perkembangan E-Commerce Bagi UMKM Di Indonesia', Jurnal Manajerial, 5.3 (2018), 184-207. p. 184.

22 Dian Rubiana Suherman, 'Arbitrase Online Dalam Penyelesaian Sengketa Business Sebagai Wujud Perlindungan Hak Konsumen', Jurnal Aktualita, 2.2 (2019), 584-597. p. 586.

${ }^{23} \mathrm{M}$ Gaertner, N. dan Smith, 'E-Commerce in a Web-Based Environment: Auditing Relative Advantages in The Australian Health Sector', Managerial Auditing Journal, 16.6 (2011), 347-365.p. 351.
} 
by obtaining a larger number of customers, through lower prices, or by providing more benefits that correspond with higher pricing. ${ }^{24}$

Competitive advantages are basically dynamic, and can not be maintained. It is because today's competition and the competition in the future must be viewed as competition with high dynamics and not something static that requires the right strategy. ${ }^{25}$

In terms of the benefits of e-commerce systems improve company performance. ${ }^{26}$ The factors that drive the implementation of e-commerce, according to Desruelle and Burgelman (2001) include: ${ }^{27}$

- Globalization and trade liberalization;

- Increasingly fierce competition;

- Technological developments;

- Reduction of physical goals; and

- Publicity.

However, there are some obstacles in its implementation. Some of the problems in the implementation of e-commerce as follows: slow Internet connections and networks that have not been thorough until all corners of Indonesia, bank administration, and distribution of goods to the buyer. While the things that support the implementation of e-commerce, namely: low costs in developing e-commerce websites and increasing the number of customers. ${ }^{28}$

Disputes in e-commerce transactions that cross national borders are resolved through online arbitration. However, in Indonesia, online arbitration has not yet been implemented. The following will describe the forms of default committed by the seller (merchant) in e-commerce transactions. A dispute is a condition in which the parties carrying out commercial efforts have a problem, namely wanting the other party to do or not do something but the other party refuses or does not do so. Disputes can also be intended as a discrepancy between individuals or groups who have a relationship because the rights of one party are disturbed or violated. ${ }^{29}$

The word arbitration comes from the Latin arbitrare which means the power to settle something according to "wisdom". The linking of the term arbitration with discretion seems to give a hint that the arbitral tribunal does not need to pay attention to the law

\footnotetext{
${ }^{24}$ Kotler Philip, “Marketing Management (New Jersey: International Edition Prentice Hall, 2003).p. 57.

${ }^{25}$ A. W Syafar, 'Membangun Daya Saing Daerah Melalui Kompetensi Khas Istinctive Competence) Berbasis Komoditi Unggulan', Jurnal Usahawan, 3.1 (2013), 1-11.p. 4.

${ }^{26}$ Vidi Arini Yulimar, 'Analisis Faktor-Faktor Yang Mempengaruhi Pengadopsian Electronic Commerce Dan Pengaruhnya Terhadap Kinerja Perusahaan (Studi Pada Perusahaan Kecil Dan Menengah Di Indonesia)' (Universitas Negeri Padang, 2006).p. 43.

${ }^{27}$ C. J. Desruelle, P. dan Burgelman, 'The Impact of E-Commerce on The Value Chain', The Journal of Policy, Regulation and Strategy for Telecomunication, Information and Media, 6.3 (2011), 485-497.p. 487.

${ }^{28}$ e. a. Ihwana, 'Empirical Study of E-Commerce Implementation among SME in Indonesia', International Journal of Independent Research and Studies, 1.1 (2012), 14-31.p. 21.

${ }^{29}$ Abdul Halim Barkatulla, 'Penyelesaian Arbitrase Online Dalam Penyelesaian Sengketa Transaksi ECommerce', Jurnal Hukum Ius Quia Iustum, 17.3 (2010), 363-382.p. 363.
} 
in resolving the disputes of the parties, but is sufficient to base it on discretion. This view is wrong because the arbitrator also applies the law as a judge does in court. ${ }^{30}$ In general, arbitration is a process in which two or more parties submit their dispute to one or more impartial persons (called arbitrators) to obtain a final and binding decision. From this understanding, three things must be fulfilled, namely: the existence of a dispute; an agreement to hand over to a third party; and a final and binding decision will be rendered. So it can be concluded that arbitration is a dispute resolution method chosen by the parties to help resolve certain disputes and provide an opinion on a certain legal relationship, to obtain a win-win solution that is final and binding for the parties so that the parties can fulfill their rights and obligations. ${ }^{31}$

Alternative dispute resolution is an out-of-court dispute resolution that the parties to the dispute are free through mutual agreement to choose the forms and procedures contained in the alternative dispute resolution and will be applied in the settlement of the dispute. One of the breakthroughs is by using an online arbitration model. ${ }^{32}$ Online arbitration is defined as a method of dispute resolution that includes all arbitration activities, including submissions to the arbitral tribunal and all proceedings taking place on the Internet via networks, e-mail, group chats, or online conferences. Arbitration as one of the mechanisms of alternative dispute resolution in international and national forums has now developed and become the main way of resolving disputes in the business sector. If we examine Article 33 of the United Nations (UN) Charter, it appears that the peaceful dispute resolution mechanism can also be applied to methods of resolving disputes (and disagreements) in the public sector, where the parties are the state or public institution. ${ }^{33}$ So it can be said that disputes or disagreements, whether business or public disputes, can be resolved through arbitration and other alternative dispute resolution mechanisms.

In Indonesia, the legal basis for arbitration has gone through several developments and changes, starting with the provisions in Article 615 to Article 651 RV (Reglement op de Bergerlijke Rechtsvordering) Article 377 HIR (Herzien Inlandsch Reglement), and Article 705 RBG (Reglement Buiten Govesten), Presidential Decree No. 34 of 1981 concerning the ratification of the 1958 New York Convention, to Act No. 30 of 1999 concerning Arbitration and Alternative Dispute Resolution. ${ }^{34}$

Article 4 paragraph (3) of Act No. 30 of 1999 concerning Arbitration and Alternative Dispute Resolution states that in the event that it is agreed that dispute resolution through arbitration occurs in the form of an exchange of letters, then the sending of telex, facsimile, e-mail, or other forms of communication means, accompanied by a note of acceptance by the parties. Thus, the parties are not required to be present

\footnotetext{
${ }^{30}$ Subekti, Arbitrase Perdagangan (Bandung: Binacipta, 1981).p. 1-3.

${ }^{31}$ Gerynica Ayu Ninghtyas, 'Penerapan Undang-Undang Nomor 30 Tahun 1999 Tentang Arbitrase Dan Alternatif Penyelesaian Sengketa Terhadap Penyelesaian Sengketa Perdagangan Online (e-Commerce) Melalui Arbitrase Online', Kumpulan Jurnal Mahasiswa Fakultas Hukum, 1.1 (2014), 1-30.p. 27.

32 M.Ali Mansyur Hutrin Kamil, 'Kajian Hukum Online Dispute Resolution (Odr) Di Indonesia Berdasarkan Undang-Undang Nomor 30 Tahun 1999', Jurnal Pembaharuan Hukum, 4.1 (2014), 111-120.p. 113.

${ }^{33}$ Yuksel. Op Cit. p. 23.

${ }^{34}$ Munir Fuady, Arbitrase Nasional (Alternatif Penyelesaian Sengketa Bisnis) (Bandung: PT. Citra Aditya Bakti, 2003).p.76.
} 
during the arbitration process on the condition that the parties have entered into a prior agreement so that if the parties cannot meet face to face in the dispute resolution process through arbitration it is not a problem. ${ }^{35}$

The online arbitration mechanism frees the determination and use of choice of law because most arbitration agreements are made in standard clauses. Arbitration dispute resolution requires adequate internet access so that the online arbitration process can run properly and is supported by other infrastructure facilities such as websites, database applications to place incoming applications, a list of arbitrators, and regulations needed for proceedings. ${ }^{36}$

In e-commerce dispute resolution, it is possible to resolve-especially those involving small-value disputes-in appropriate forums. ${ }^{37}$ There are various reasons why people choose arbitration forums as a private dispute resolution method, including: ${ }^{38}$

- Freedom, Trust, and Security;

- Expertise;

- Fast and Cost-Effective;

- Confidential;

- The consideration of the arbitral decision is more private;

- Modern Trends;

- The arbitration decision is final and binding.

Internet technology in particular has brought a change in business practices and marketing, where almost all of the activities and practices of business, commerce, and marketing can be executed electronically. This can be seen in terms/words such as electronic business (e-business), electronic commerce (e-commerce), and electronic marketing (e-marketing) which means that these disciplines have been applied in information and communication technology (ICT) and have been practiced electronically. ${ }^{39}$

The development of the internet allows online dispute resolution. Implementation of arbitration is online is by using the internet. The completeness required is an internet service that can meet the needs of the implementation of the arbitration. The parties must also be provided with a room to communicate with each other. The room for communication is like a chat room based on real-time audio-visual streaming. With the application to communicate, the parties can convey their data, facts, information, or responses through this channel. In the absence of rigid formal rules in this online

\footnotetext{
35 Rizky Novian Margono, ‘Pengembangan Hukum Penyelesaian Sengketa Bisnis Dengan Metode Arbitrase Online Di Indonesia', Risalah Hukum, 5.2 (2013), 72-84.p. 77.

${ }^{36}$ Solikhah, 'Prospek Arbitrase Online Sebagai Upaya Penyelesaian Sengketa Di Luar Pengadilan Ditinjau Dari Hukum Bisnis', Diponegoro Law Journal, 6.2 (2009), 1-15.p.7.

${ }^{37}$ Karen Alboukrek, 'Adapting to A New World of E-Commerce: The Need for Uniform Consumer Protection in the International Electronic Marketplace', George Washington International Law Review, 35.2 (2003), 420-431.p. 422.

${ }^{38}$ Eman Suparman, Pilihan Forum Arbitrase Dalam Sengketa Komersial Untuk Penegakan Keadilan (Jakarta: PT Tata Nusa, 2004).p. 3.

${ }^{39}$ Alexander Harsono, 'Understanding E-Business \& E-Commerce And Their Relation To The Conceptual Framework Of Emarketing: Case Study', Jurnal Informatika Dan Komputer, 2.1 (2011), 50-64.p.53.
} 
arbitration process, it is hoped that the parties will be calmer and able to convey the facts.

The arbitration institution determines whether to carry out the online process or not because it only accepts cases related to online activities, such as e-commerce breaches. Regarding the online arbitration procedure, the details are as follows: ${ }^{40}$

- Agreement to resolve disputes through online arbitration; The parties must consider the procedures of the particular arbitration institution that will be used in the settlement of their dispute as part of the arbitration agreement. The arbitration institution that has been chosen cannot carry out its duties properly if the parties do not have the capacity to resolve disputes through arbitration and/or disputes that occur are not related to the trade sector or other fields that have been determined.

- Notification to the parties and calculation of the dispute resolution period; Based on the agreement of the parties and the approval of the arbitrator, every document made based on the procedures of the arbitration institution that has been selected must have been sent by e-mail. The time and day of receipt of the document via email will be determined as the time the document is made by the parties. The settlement period will be calculated from the receipt of the document. The settlement period will be calculated from the receipt of the document.

- Claims filed in online arbitration; The applicant must produce a document containing the claim. Claims in arbitration must include the arbitration agreement, the agreement between the two parties regarding the amount, identity, qualifications, and method of appointment of the arbitrator, a statement regarding the dispute, the legal reasons behind the claim, the amount of compensation desired (if any). The applicant must pay a fee 5 (five) days before the filing of the claim. Such fees may be paid electronically, or by any other method determined by the arbitral tribunal.

- Notice of claim; After the payment is made, the arbitration institution will then examine the claim submitted by the applicant. If the claim is appropriate, within 5 (five) working days, the arbitration institution will notify the parties. If the respondent cannot be notified by e-mail, the arbitration institution will determine that the selected procedure, namely online arbitration, cannot be carried out.

- Answer to claim; Within 30 (thirty) days as of the creation of the case site, the respondent must answer the claim.

- Answer to counterclaim; If the respondent files a counterclaim, the applicant must respond to the counterclaim within 30 days from the receipt of the counterclaim. The applicant's answer must include the information specified in point 5.

- Extension of the dispute resolution period; The arbitrator for a reasonable reason may extend the term.

- Language used; The language used in dispute resolution is the language used in the arbitration agreement unless otherwise determined by the parties or based on the authority of the arbitrator.

\footnotetext{
${ }^{40}$ Moch Basarah.Op.Cit, p.31
} 
- Hearing process; If the parties with the approval of the arbitrator agree to carry out the hearing process, the arbitrator will make an arbitration award based on the compliance of the parties. If no hearing process is carried out, the arbitrator will decide within 30 days from the closing of the process. In the hearing process, testimony can be accepted, cross-examination of witnesses can be carried out and additional documents can be accepted as evidence by the arbitrator.

- Place of judgment; The place of the verdict can be determined by the parties, if the parties do not determine, then the place of the verdict is determined by the arbitrator.

- Telling the contents of the decision; The time and date the decision is sent are set as the date and time the decision is made.

- Communication method used; The arbitrator can determine the communication method to be used apart from the communication method used in the site case. The arbitral tribunal must provide e-mail addresses for the parties as well as for the arbitrator, through which they can communicate with each other.

Regarding dispute resolution through arbitration institutions during this Covid19 pandemic, Indonesia is still waiting for an internal study from the Indonesian National Arbitration Board (BANI) where the online arbitration settlement process will be carried out by video conference. This consideration must be carried out with an indepth study considering that arbitration is confidential and must be kept confidential.

\subsection{Legal Sanctions Against Online Buying and Selling Transactions that do not in accordance with the Order}

Buying and selling transactions, even though they are carried out online, based on the ITE Law and PP PSTE are still recognized as legal and accountable electronic transactions. If an online buying and selling product produced by a business actor results in a loss to the consumer, the business actor is obliged to compensate for all the losses suffered by the consumer and receive sanctions under the laws and regulations. The thing to remember is that buying and selling online in principle is the same as buying and selling factually in general.

Online buying and selling transactions are difficult to execute or take real action in the event of a dispute or a criminal act of fraud. The nature of cyber in electronic transactions allows everyone, both sellers and buyers, to disguise or fake identity in every transaction or sale and purchase agreement. If a business actor or seller turns out to be using a false identity or committing deception in online buying and selling, then he or she can also be punished under Article 378 of the Criminal Code ("KUHP") and Article 28 paragraph (1) of the ITE Law.

Article 378 of the Criminal Code said, "Whoever with the intention of unlawfully benefiting himself or another person, by using a false name or false dignity, by deceit, or a series of lies, moves another person to hand over something to him, or to give a debt or write off a debt, is threatened because of fraud with a maximum imprisonment of 4 years." 
Article 28 paragraph (1) of the ITE Law said, "Everyone intentionally and without rights spreads false and misleading news that results in consumer losses in Electronic Transactions."

Violation of Article 28 paragraph (1) of the ITE Law is subject to criminal sanctions in Article 45A paragraph (1) of Act No. 19 of 2016, namely: "Everyone who intentionally and without rights spreads false and misleading news that results in consumer losses in Electronic Transactions as referred to in Article 28 paragraph (1) shall be punished with imprisonment for a maximum of 6 years and/or a fine of a maximum of IDR 1 billion."

Thus there are general rules (Lex Generalis) and special rules (Lex Specialist) which regulate legal sanctions against online buying and selling transactions that do not match orders, general rules (Lex Generalis) can be categorized as a criminal act of fraud which is regulated in Article 378 of the Criminal Code which carries a penalty of 4 (four) years in prison. In addition, a special rule (Lex Specialist) is regulated in Article 28 paragraph 1 of the ITE Law where the action is categorized as spreading false news that causes consumer losses in electronic transactions. The criminal threat is a maximum of 6 years and/or a maximum fine of IDR 1 billion.

\section{Conclusion}

From the results of the discussion of the problems above, it can be concluded that the process of implementing online arbitration is using the internet. The completeness required is an internet service that can meet the needs of the implementation of the arbitration. The parties must also be provided with a room to communicate with each other. The room for communication is like a chat room based on real-time audiovisual streaming. With the application to communicate, the parties can convey their data, facts, information, or responses through this channel. Sanctions if there is a default in buying and selling transactions through online media, are regulated in general rules (Lex Generalis) and special rules (Lex Specialist). The general rules (Lex Generalis) can be categorized as a criminal act of fraud as regulated in Article 378 of the Criminal Code which carries a penalty of 4 (four) years in prison. In addition, the special rule (Lex Specialist) is regulated in Article 28 paragraph 1 of the ITE Law where the action is categorized as spreading false news that causes consumer losses in electronic transactions. The criminal threat is a maximum of 6 years and/or a maximum fine of IDR 1 billion.

\section{References}

\section{Journals:}

[1] Alboukrek, Karen, 'Adapting to A New World of E-Commerce: The Need for Uniform Consumer Protection in the International Electronic Marketplace', George Washington International Law Review, 35.2 (2003), 420-31

[2] Alexander W. Bartik, Marianne Betrand, Zoe Cullen, Edward L. Glaeser, Michael Luca, Christopher Stanton, 'The Impact of COVID-19 on Small Business Outcomes and Expectations', Proceedings of the National Academy of Sciences, 117.30 
(2020), 17656-66

[3] Barkatulla, Abdul Halim, 'Penyelesaian Arbitrase Online Dalam Penyelesaian Sengketa Transaksi E-Commerce', Jurnal Hukum Ius Quia lustum, 17.3 (2010), 363-82

[4] Benuf, Kornelius, and Muhamad Azhar, 'Metodologi Penelitian Hukum Sebagai Instrumen Mengurai Permasalahan Hukum Kontemporer', Gema Keadilan, 7.1 (2020), 20-33

[5] Depri Liber Sonata, 'Metode Penelitian Hukum Normatif Dan Empiris Karakteristik Khas Dari Metode Meneliti Hukum', Fiat Justisia Jurnal Ilmu Hukum, 8.1 (2014), 15-35

[6] Desruelle, P. dan Burgelman, C. J., 'The Impact of E-Commerce on The Value Chain', The Journal of Policy, Regulation and Strategy for Telecomunication, Information and Media, 6.3 (2011), 485-97

[7] Gaertner, N. dan Smith, M, 'E-Commerce in a Web-Based Environment: Auditing Relative Advantages in The Australian Health Sector', Managerial Auditing Journal, 16.6 (2011), 347-65

[8] Harsono, Alexander, 'Understanding E-Business \& E-Commerce And Their Relation To The Conceptual Framework Of Emarketing: Case Study', Jurnal Informatika Dan Komputer, 2.1 (2011), 50-64

[9] Hutrin Kamil, M.Ali Mansyur, 'Kajian Hukum Online Dispute Resolution (Odr) Di Indonesia Berdasarkan Undang-Undang Nomor 30 Tahun 1999', Jurnal Pembaharuan Hukum, 4.1 (2014), 111-20

[10] Ihwana, e. a., 'Empirical Study of E-Commerce Implementation among SME in Indonesia', International Journal of Independent Research and Studies, 1.1 (2012), 14-31

[11] Mahir Pradana, 'Klasifikasi Jenis-Jenis Bisnis E-Commerce Di Indonesia', Neo-Bis, 9.2 (2015), 32-40

[12] Margono, Rizky Novian, 'Pengembangan Hukum Penyelesaian Sengketa Bisnis Dengan Metode Arbitrase Online Di Indonesia', Risalah Hukum, 5.2 (2013), 72-84

[13] Ninghtyas, Gerynica Ayu, 'Penerapan Undang-Undang Nomor 30 Tahun 1999 Tentang Arbitrase Dan Alternatif Penyelesaian Sengketa Terhadap Penyelesaian Sengketa Perdagangan Online (e-Commerce) Melalui Arbitrase Online', Kumpulan Jurnal Mahasiswa Fakultas Hukum, 1.1 (2014), 1-30

[14] Orna Rabinovich-Einy, Ethan Katsh, 'Digital Justice : Reshaping Boundaries in an Online Dispute Resolution Environment', International Journal of Online Dispute Resolution, 1.1 (2014), 1-10

[15] Purwanto, Efektivitas Penerapan Alternative Dispute Resolution (Adr) Pada Penyelesaian Sengketa Bisnis Asuransi Di Indonesia (Samarinda: Risalah Hukum, 2015)

[16] Rochani Urip, Rahadi Wasi Bintoro, 'Alternatif Penyelesaian Sengketa Dalam Transaksi Elektronik (E-Commerce)', Jurnal Dinamika Hukum, 13.1 (2013), 12338

[17] Shabur Mirftah Maulana, 'Implementasi E-Commerce Sebagai Media Penjualan Online', Jurnal Administrasi Bisnis, 29.1 (2020), 1-9

[18] Sjahdeini, Sutan Remy, 'E-Commerce (Tinjauan Dari Perspektif Hukum)', Jurnal 
Hukum Bisnis, 6.6 (2018), 23-43

[19] Solikhah, 'Prospek Arbitrase Online Sebagai Upaya Penyelesaian Sengketa Di Luar Pengadilan Ditinjau Dari Hukum Bisnis', Diponegoro Law Journal, 6.2 (2009), 115

[20] Suherman, Dian Rubiana, 'Arbitrase Online Dalam Penyelesaian Sengketa Business Sebagai Wujud Perlindungan Hak Konsumen', Jurnal Aktualita, 2.2 (2019), 584-97

[21] Susilo, J Adityo, 'Coronavirus Disease 2019: Tinjauan Literatur Terkini', Jurnal Penyakit Dalam Indonesia, 7.1 (2019), 45-67

[22] Syafar, A. W, 'Membangun Daya Saing Daerah Melalui Kompetensi Khas Istinctive Competence) Berbasis Komoditi Unggulan', Jurnal Usahawan, 3.1 (2013), 1-11

[23] Wicaksono Febriantoro, 'Kajian Dan Strategi Pendukung Perkembangan ECommerce Bagi UMKM Di Indonesia', Jurnal Manajerial, 5.3 (2018), 184-207

[24] Yuksel, Armagan Ebru Bozkurt, 'Online International Arbitration', Ankara Law Review, 4.1 (2007), 1-12

[25] Yulimar, Vidi Arini, 'Analisis Faktor-Faktor Yang Mempengaruhi Pengadopsian Electronic Commerce Dan Pengaruhnya Terhadap Kinerja Perusahaan (Studi Pada Perusahaan Kecil Dan Menengah Di Indonesia)' (Universitas Negeri Padang, 2006)

[26] Yulistia, 'Analisis Pengaruh Efektivitas Dan Manfaat E-Commerce Terhadap Sikap Dan Perilaku Pengguna Dengan Menggunakan Metode TAM (Studi Kasus: UKM Kota Palembang)', JATISI (Jurnal Teknik Informatika Dan Sistem Informasi), 4.1 (2017), 93-100

\section{Books:}

[1] Cortes, Pablo. 2011. Online Dispute Resolution for Consumer in the European Union New York. Routledge

[2] Moch Basarah. 2011. Prosedur Alternatif Penyelesaian Sengketa Arbitrase Internasional Bandung. Genta Publishing

[3] Munir Fuady. 2003. Arbitrase Nasional (Alternatif Penyelesaian Sengketa Bisnis). Bandung. PT. Citra Aditya Bakti

[4] Paustinus Siburian. 2004. Arbitrase Online (Alternatif Penyelesaian Sengketa Perdagangan Secara Elektronik) . Jakarta. Djambatan

[5] Philip, Kotler. 2003. Marketing Management. New Jersey. International Edition Prentice Hall

[6] Priyatna Abdurrasyid. 2002. Arbitrase \& Alternatif Penyelesaian Sengketa (Jakarta: Fikahati Aneska.

[7] Purwanto. 2015. Efektivitas Penerapan Alternative Dispute Resolution (Adr) Pada Penyelesaian Sengketa Bisnis Asuransi Di Indonesia. Samarinda. Risalah Hukum.

[8] Soerjono Soekanto. 2001. Sri Mamudji, Penelitian Hukum Normatif; Suatu Tinjauan Singkat. Jakarta. Raja Grafindo Persada

[9] Subekti. 1981. Arbitrase Perdagangan. Bandung: Binacipta

[10] Suparman, Eman. 2004. Pilihan Forum Arbitrase Dalam Sengketa Komersial Untuk Penegakan Keadilan. Jakarta: PT Tata Nusa

[11] Susanti Adi Nugroho. 2009. Mediasi Sebagai Alternatif Penyelesaian Sengketa 
Jakarta: Telaga IImu Indonesia

\section{Thesis:}

[1] Yulimar, Vidi Arini, 'Analisis Faktor-Faktor Yang Mempengaruhi Pengadopsian Electronic Commerce Dan Pengaruhnya Terhadap Kinerja Perusahaan (Studi Pada Perusahaan Kecil Dan Menengah Di Indonesia)' (Universitas Negeri Padang, 2006)

\section{Internet:}

[1] Rizal

Fadli, 'Coronavirus', Halodoc, 2021 <https://www.halodoc.com/kesehatan/coronavirus> [accessed 29 June 2021] 